\title{
MIEJSCE NAZW JEDNOSTEK ADMINISTRACYJNYCH W CHORONIMII
}

Słow a tematyczne: geonimy, choronimy, nazwy jednostek administracyjnych, egzonimy

W 2016 roku ukazał się słowniczek Michała Garcarza poświęcony slangowym rozwinięciom literowych kodów powiatów na tablicach rejestracyjnych pojazdów (Garcarz, 2016). Czytałam tę zabawną książeczkę okiem językoznawcy i onomasty, zastanawiając się nad statusem onimicznym nazw jednostek administracyjnych i ich literowych kodów ${ }^{1}$ oraz przyglądając się ich relacjom z innymi toponimami. W poniższym artykule chcę się podzielić swoimi refleksjami, wątpliwościami teoretycznymi i doświadczeniami praktyka-standaryzatora.

W ogólnym podziale nazw geograficznych (geonimów) obok ojkonimów i anojkonimów wymienia się także choronimy (Olivová-Nezbedová, 2002, s. 83), rozumiane jako nazwy państw, krain, regionów geograficznych i historycznych, jednostek administracyjnych itp. ${ }^{2}$ Dwa pozostałe terminy odnoszą się do nazw miejscowości (ojkonimy) i nazw miejsc niezamieszkanych (anojkonimy). Choronimy wśród polskich onomastów nie budziły takiego zainteresowania, jak ojkonimy i anojkonimy ${ }^{3}$. Symptomatyczne, że w dużych kompendiach onomastycznych, takich jak „Polskie nazwy własne” czy „Słowiańska onomastyka” nie przewidziano osobnego rozdziału, poświęconego tej tematyce, choronimia nie występuje także w indeksie terminów ${ }^{4}$. Podała go natomiast Maria Malec

${ }^{1}$ Literowym kodom jednostek administracyjnych poświęcony będzie osobny artykuł.

${ }^{2}$ Por. także STUS, hasło ang. choronym, pol. choronim, 'toponim stosowany do obiektów powierzchniowych'. A. Czerny, wymieniając działy toponimii, opisuje choronimy jako ,nazwy obszarów: regionów geograficznych i jednostek administracyjnych, np. Sahara, Mazowsze, Bawaria, województwo pomorskie" (Czerny, 2011, s. 16).

${ }^{3}$ Z polskich opracowań choronimów por. np.: Karpluk (1986); Zierhoffer, Zierhofferowa (2000, 2007, 2011); Siatkowski (2006); Zych (2014).

${ }^{4}$ Ściślej: w „Słowiańskiej onomastyce” choronim nie występuje w indeksie polskim, jest natomiast $\mathrm{w}$ indeksie czeskim i rosyjskim. 
w popularnym „Słowniku etymologicznym nazw geograficznych Polski”, objaśniając jako „nazwy krajów i krain” (2003, s. 284).

Status proprialny nazw państw, krain i dzielnic historycznych oraz regionów geograficznych i etnograficznych nie budzi wątpliwości, np.: Polska, Mazowsze, Śląs, Roztocze, Kurpie. Inaczej jest z nazwami jednostek podziału administracyjnego. Wewnętrzny podział terytorialny należy do kompetencji poszczególnych państw, a jego celem jest usprawnienie zarządzania przez urzędy. Jednostki podziału administracyjnego (terytorialnego) mają jasno wytyczone granice ${ }^{5} \mathrm{i}$ ustalone siedziby władz, pokrywają też cały obszar kraju. Nazwy jednostek ustanawia upoważnione, urzędowe gremium, wypracowujące w miarę spójną i jednolitą nomenklaturę. Różna wielkość obszaru, ukształtowanie powierzchni, historia, tradycja czy skład narodowościowy — to tylko niektóre z czynników kształtujących systemy nazewnicze jednostek administracyjnych w poszczególnych państwach. W dużych krajach podstawowe jednostki podziału bywają większe niż niejedno samodzielne państwo. Są i takie kraje, w których wewnętrzne podziały nie są w ogóle potrzebne.

Urzędowy charakter to specyficzna cecha nazw jednostek administracyjnych, która łączy ten zbiór ze współczesnymi nazwami państw świata (w nazwach krain historycznych czy regionów status urzędowy nie ma takiego znaczenia). Z kolei systemowość i kompletność zbliżają nazwy jednostek administracyjnych z terminologią specjalistyczną, np. w podobny sposób powstaje nazewnictwo w geografii regionalnej (por. np. Kondracki, 1969) czy — przyjęte na całym świecie hydrograficzne nazewnictwo mórz i oceanów, ustalane przez Międzynarodową Organizację Hydrograficzną. W literaturze przedmiotu już dość dawno wyróżniono dwie grupy nazw geograficznych właśnie ze względu na sposób ich tworzenia: jedne są nadane w jednorazowym akcie nominacji (oficjalnym lub nieoficjalnym), inne powstają w wyniku długotrwałej, naturalnej ewolucji (Stewart, 1975; za: Czerny, 2011, s. 44). Nazwy jednostek administracyjnych należą do pierwszej grupy. Przy ich ustalaniu istotna jest struktura konceptualna całego zbioru oraz prymat systemowości i jednomianowości (tzn. jedno oznaczenie dla jednego pojęcia). Zasady te są wspólne z zasadami opracowywania terminów specjalistycznych (Mazur, 1961; PN-ISO 704, 2012).

W polskiej tradycji normatywnej nazwy województw i powiatów, a także historycznych ziem, zaliczane są do apelatywów, np.: województwo mazowieckie, powiat piaseczyński, ziemia tęczycka. Tę zasadę zaburza istnienie powiatów grodzkich, ponieważ ich nazwy są identyczne z nazwami miast, np. Zamość. Podobnie nazwy gmin są bez wyjątku tożsame z nazwami miejscowości, np. Lesznowola.

\footnotetext{
${ }^{5}$ Zdarzają się od tej zasady wyjątki, np. w Ameryce Południowej.
} 
Maria Biolik zaproponowała dla takich nazw termin homonim kategorialny: „Jednostki onimiczne identyczne formalnie, ale różniące się znaczeniem kategorialnym wyrażonym przynależnością do różnych kategorii onimicznych, można nazwać homonimami kategorialnymi”. Ilustracją tego zjawiska jest m.in. przykład: Wisła - rzeka, Wisła - miasto (Biolik, 2009, s. 41-43).

W „Polskim przewodniku toponimicznym” (TG), będącym rodzajem podręcznika (głównie dla redaktorów map) ${ }^{6}$, o nazwach jednostek podziału administracyjnego naszego kraju podano następującą informację:

Województwa mają nazwy pochodzące od nazw regionów geograficzno-historycznych (13 województw) lub od nazw głównych miast (3 województwa). Nazwy województw ustalone zostały w formie przymiotnikowej, a oba człony ich nazwy należy pisać małą literą" (s. 79); [...] Powiaty w większości nazwane zostały od nazw ich siedzib, trzy powiaty mają nazwy pochodzące od nazw dwóch głównych miast powiatu, a dwa ${ }^{7}$ mają nazwy pochodzące od nazw regionów geograficznych. Nazwy powiatów ziemskich ustalone zostały w formie przymiotnikowej z pierwszym członem ,powiat”. Wszystkie człony nazwy należy pisać małą literą, np. powiat zamojski, powiat rypiński. W przypadku powiatów grodzkich nie ma w ich nazwie członu „powiat”, a nazwy zapisuje się w mianowniku wielką literą, np. Zamość (tzn. nazwa powiatu jest identyczna z nazwą miasta) (s. 80).

W zbiorze nazw jednostek podziału administracyjnego Polski znajdują się zatem zarówno nazwy pospolite, jak i własne. O przynależności do konkretnego podzbioru decyduje postać językowa, mianowicie apelatywne są zestawienia $\mathrm{z}$ terminami gatunkowymi ${ }^{8}$ województwo, powiat oraz przymiotnikiem odmiejscowym, natomiast propriami są nazwy tożsame z nazwami miast i wsi; trudno sobie wyobrazić, że w imię czystości systemowej polecana byłaby pisownia typu zamość w nazwach powiatów grodzkich i w nazwach gmin. Zauważmy, że takie formy językowe, jak Lubelszczyzna, Suwalszczyzna czy Łódzkie, Przemyskie (często pojęciowo ekwiwalentne nazwom województwa lub powiatu), traktujemy jako nazwy regionów, a więc na równi z nazwami takimi, jak Małopolska czy Pomorze $e^{9}$.

\footnotetext{
${ }^{6}$ Narodowe wersje TG powstają według schematu tematycznego wypracowanego przez UNGEGN (Grupę Ekspertów ONZ ds. Nazw Geograficznych). Zawierają m.in.: ogólne informacje o języku (językach) używanych w danym państwie, zasadach pisowni nazw geograficznych, zasadach transkrypcji oraz podziałach administracyjnych. Kierowane są nie tylko na rynek wewnętrzny, ale także - w thumaczeniu na język angielski — do całej społeczności międzynarodowej za pośrednictwem UNGEGN.

${ }^{7}$ Obecnie są to trzy nazwy, ponieważ pow. jeleniogórski zmieniono na karkonoski.

8 Termin gatunkowy, zwany także terminem rodzajowym (ang. generic term), to rzeczownik pospolity, który określa obiekt topograficzny przez jego cechy, a nie nazwę własną (np. pol. góra). Może być częścią toponimu, wówczas nazywany jest elementem gatunkowym albo elementem rodzajowym (ang. generic element), np. Sierra Nevada, Newport — por. STUS.

${ }^{9}$ O funkcji nazw współczesnych województw i ich miejscu wśród nazw własnych pisała też M. Sagan-Bielawa (2017).
} 
Kwestia statusu onomastycznego nazw jednostek administracyjnych komplikuje się znacznie bardziej, jeśli uwzględnimy inne kraje świata.

W polskim wykazie egzonimów (tradycyjnych polskich nazw obiektów geograficznych spoza granic kraju) ${ }^{10}$ obok nazw krajów i regionów uwzględniamy także urzędowe nazwy jednostek administracyjnych. Jest wśród nich bardzo wiele form zapożyczonych z języków pośredniczących, takich jak francuski czy rosyjski. Standaryzując nazwy geograficzne świata, mamy na uwadze nie tylko polskie przepisy normatywne, ale także zasady ortograficzne $w$ innych językach oraz uzus ${ }^{11}$ (niekiedy wieloletni), odbiegający od polskich zaleceń poprawnościowych a polegający na kalkowaniu zapisów oryginalnych. Współczesny uzus jest w dużym stopniu kształtowany przez globalną sieć informatyczną, w której angielszczyzna odgrywa największą rolę. W efekcie tych różnych czynników zbiór polskich nazw jednostek administracyjnych na świecie zawiera wiele niekonsekwencji zarówno ściśle językowych (np. odmienność — nieodmienność), jak i pozajęzykowych, ortograficznych. W odniesieniu m.in. do nazw państw i regionów fizycznogeograficznych wskazywał na to Andrzej Czerny (2021), rozważając przy okazji także kwestię terminów gatunkowych w nazwach. Słusznie zauważył:

[...] Zasady pisowni nie biorą pod uwagę tego, że mogą zachodzić dwa różne przypadki. Z punktu widzenia standaryzacji nazw geograficznych termin gatunkowy może pełnić dwojaką funkcję: - stanowić integralną część toponimu, zwaną elementem gatunkowym albo członem utożsamiajacym, np. Sierra Nevada (hiszp. 'góry śnieżne'), Wyżyna Kolorado (ang. Colorado Plateau, w odróżnieniu od rzeki Kolorado), Rów Riukiu (rów oceaniczny na Pacyfiku, od nazwy wysp Riukiu);

- charakteryzować obiekt, nie będąc częścią toponimu, np. miasto Chicago, die Gebirge Hunsrück und Taunus (niem. 'góry Hunsrück i Taunus').

Odróżnienie dwuwyrazowych nazw geograficznych zawierających element gatunkowy od luźnych połączeń wyrazowych jest istotne, ponieważ element gatunkowy należy pisać wielką literą, a termin niebędący częścią nazwy — małą. Pisownia endonimu nie jest właściwą wskazówką, ponieważ — inaczej niż po polsku — element gatunkowy może być pisany małą literą, nawet wtedy, gdy drugi człon nazwy jest przymiotnikiem, np. fr. mer du Nord ('Morze Północne'), hiszp. mar Mediterraneo ('Morze Śródziemne'), ros. Beloe more ('Morze Białe') (s. 82-83).

Niniejszy artykuł jest w pewnym zakresie kontynuacją i uzupełnieniem problematyki, przedstawionej przez A. Czernego, z którego ustaleniami i wnioskami

${ }^{10}$ Podaję tu przybliżone objaśnienie terminu, którego definicja ulegała z czasem daleko idącej ewolucji. Komisja Standaryzacji Nazw Geograficznych poza Granicami Rzeczypospolitej Polskiej przyjęła, że „polski egzonim to nazwa obecnie używana w Polsce w języku polskim dla obiektu geograficznego leżącego poza jej terytorium i różniąca się zapisem od endonimu standaryzowanego tego obiektu" (UWPNG, s. XVIII). Endonim to nazwa obiektu geograficznego w języku używanym na obszarze, gdzie ten obiekt się znajduje (STUS).

${ }^{11}$ Wnikliwą analizę uzusu toponimicznego w ujęciu teoretycznym zawiera monografia W. Włoskowicza (2021). 
całkowicie się zgadzam. W przeglądzie nazw jednostek administracyjnych we współczesnych państwach wykorzystałam „Urzędowy wykaz polskich nazw geograficznych świata" (UWPNG). Podano w nim nazwy jednostek podstawowego podziału administracyjnego (jednostki pierwszego rzędu), a w określonych przypadkach także jednostki drugiego rzędu. Zdarza się, że nazwy jednostek administracyjnych mają dwie polskie nazwy urzędowe: krótką (np. Sardynia, Bawaria) i oficjalną, zazwyczaj bardziej rozbudowaną, używaną w stosunkach oficjalnych (np. Region Autonomiczny Sardynii, Wolny Kraj Bawaria). W przykładach podanych poniżej zapisy oryginalne w alfabetach innych niż łaciński występują w transkrypcji według UWPNG. W krajach, w których obok języków dla nas egzotycznych językiem urzędowym jest angielski, francuski itp., podaję tylko zapisy w tych ostatnich, ponieważ to one stanowiły podstawę przyswojenia w polszczyźnie.

Najczęściej polskie nazwy jednostek administracyjnych w różnych państwach świata ustalone zostały w postaci homonimicznej z nazwami miast lub regionów geograficznych, np. Tyrol (Austria, niem. Tirol), Sofia (Bułgaria, bułg. Sofija), nawet jeśli w oryginale występował termin gatunkowy (jak w nazwach kantonów w Szwajcarii), np. Lucerna (niem. Kanton Luzern). Odpowiednikiem takich form są polskie nazwy powiatów grodzkich i gmin, np. powiat Zamość, gmina Lesznowola. Kalki z członem Wielki, Wielka: Wielki Londyn (Wielka Brytania, jedn. II rzędu, ang. Greater London), Wielka Akra (Ghana, ang. Greater Accra) są modelem nazewniczym przeniesionym z nazw regionów, gdzie występują częściej, np. Wielka Moskwa (Rosja), Wielki Kair (Egipt), Wielkie Tokio (Japonia). Wyjątkową formę w polskim zbiorze jednostek egzonimicznych mają nazwy Bazylea-Miasto i Bazylea-Okręg (Szwajcaria, niem. Basel-Stadt, BaselLandschaft), zawierające element gatunkowy i zapisane z dywizem.

Polskie nazwy krajów w Czechach i na Słowacji, obwodów i rejonów na Białorusi, żupanii w Chorwacji, ajmaków w Mongolii czy wilajetów w Turkmenistanie i Uzbekistanie mają postać zestawień z terminem gatunkowym i przymiotnikiem od nazwy głównego miasta lub regionu; takie nazwy są zapisywane małą literą, czyli podobnie, jak nazwy naszych województw i powiatów ziemskich. Przykłady: obwód brzeski (Białoruś, jedn. I rzędu, błr. Bresckaja wobłasć, ros. Briestskaja obłast'), rejon baranowicki (Białoruś, jedn. II rzędu, błr. Baranawicki rajon, ros. Baranowiczskij rajon), kanton sarajewski (Bośnia i Hercegowina, jedn. II rzędu, boś. Kanton Sarajevo, chorw. Sarajevska županija, serb. Kanton Sarajevo), obwód sofijski (Bułgaria, bułg. Sofijska obłast) ${ }^{12}$, żupania zagrzebska (Chorwacja, chorw. Zagrebačka županija), kraj pardubicki

12 Jest to jedyna nazwa jednostki I rzędu w Bułgarii, która nie jest homonimiczna z nazwą miejscowości. Polskie egzonimy oddają zróżnicowanie w języku oryginału, por. pol. Sofia oraz obwód sofijski i bułg. Sofia, ofic. Obłast Sofija oraz Sofijska obłast. 
(Czechy, czes. Pardubický kraj), obwód atmacki (Kazachstan, kaz. Atmaty obłysy, ros. Atmatinskaja obłast'), obwód naryński (Kirgistan, kirg. Naryn oblusu, ros. Narynskaja obłast'), okręg kowieński (Litwa, jedn. I rzędu, lit. Kauno apskritis), rejon birżański (Litwa, jedn. II rzędu, lit. Biržu rajono savivaldybė), ajmak uwski (Mongolia, mong. Uws ajmag), obwód kaliningradzki (Rosja, jedn. I rzędu, ros. Kaliningradskaja obłast'), kraj koszycki (Słowacja, słc. Košický kraj), wilajet achalski (Turkmenistan, turkm. Ahal welaýaty), obwód lwowski (Ukraina, jedn. I rzędu, ukr. Lwiwśka obłast'), rejon barski (Ukraina, jedn. II rzędu, ukr. Barśkyj rajon), wilajet bucharski (Uzbekistan, uzb. Buxoro viloyati).

Ten model nazewnictwa jednostek administracyjnych w polskiej tradycji geograficzno-kartograficznej stosowany jest głównie dla krajów słowiańskich, zapewne ze względu na bliskość języków, które nie stwarzają barier dla tłumaczenia struktur oryginalnych, podobnych w budowie, chociaż o innym statusie onimicznym, por. np. polskie kraj liberecki, oryginalnie czes. Liberecký kraj. W krajach azjatyckich taki model nazewniczy jest spuścizną czasów, kiedy należały one do ZSRR a ich nazewnictwo administracyjne znane było w Polsce w rosyjskiej wersji językowej. Należy podkreślić, że we wszystkich powyższych przykładach polskie nazwy odbiegają pod względem szyku od oryginału, ponieważ tylko w polskiej tradycji normatywnej w nazwach złożonych termin gatunkowy stoi na pierwszej pozycji.

Od wskazanego wyżej sposobu polszczenia nazw jednostek administracyjnych są jednak wyjątki, np. w Rosji mamy takie jednostki I rzędu, jak Kraj Chabarowski, Kraj Permski (ros. Chabarowskij kraj, Piermskij kraj), czy jednostki II rzędu, jak Okręg Komi-Permiacki (ros. Komi-Piermiackij okrug), w których wielką literą zapisano wszystkie człony. W nazwach wieloelementowych termin gatunkowy pojawia się na dalszych pozycjach, co pozwala uznać go za element gatunkowy (tzn. składnik nazwy własnej) i umożliwia pisownię wielką literą całej nazwy, np. Nieniecki Okręg Autonomiczny (jedn. I rzędu, ros. Nienieckij avtonomnyj okrug). W Europie Zachodniej nazwy podobne pod względem budowy są rzadsze, por. Region Waloński (Belgia, fr. Région wallone, od nazwy krainy Walonia) czy Wspólnota Walencka (Hiszpania, nazwa oficjalna obok krótkiej Walencja, hiszp. Comunidad Valenciana).

W wielu krajach afrykańskich, w Ameryce Południowej i Azji nazwy jednostek administracyjnych składają się z elementu gatunkowego i przymiotnika wskazującego na położenie obiektu względem stron świata, jego charakter ustrojowy lub rolę administracyjną. Obowiązuje tu zapis wielkimi literami we wszystkich członach nazwy, łącznie z elementem gatunkowym. Przykłady: Departament Centralny (Paragwaj, hiszp. Departamento Central), Departament Centralny (Haiti, fr. Département du Centre), Dependancje Federalne (Wenezuela, hiszp. 
Dependancias Federales), Dystrykt Centralny (Botswana, ang. Central District), Dystrykt Federalny (Brazylia, port. Distrito Federal), Dystrykt Poludniowy (Liban, arab. Muhafazat al-Dżanub), Dystrykt Stołeczny (Dominikana, hiszp. Distrito National), Prowincja Centralna (Zambia, ang. Central Province), Prowincja Centralna (Papua-Nowa Gwinea, ang. Central Province; tak samo na Wyspach Salomona), Prowincja Potudniowa (Rwanda, fr. Province du Sud), Prowincja Stoleczna (Kuwejt, arab. Muhafazat al-Asima), Prowincja Wschodnia (Arabia Saudyjska, arab. Al-Mintaka Asz-Szarkijja), Region Centralny (Erytrea, ang. Central Region; tak samo w Kamerunie czy Malawi), Region Stoleczny (Dania, duń. Region Hovedstaden), Region Stołeczny (Filipiny, ang. National Capital Region/Metropolitan Manila), Rejony Administrowane Centralnie (Tadżykistan, tadż. Nohijahoi tobei dżumhuri).

Na sposób zapisu wielu podanych wyżej polskich egzonimów niewątpliwie wpływ miała forma oryginału. Według polskiej tradycji nazewniczej zapis wielką literą każe takie nazwy zaliczać do propriów, chociaż pod względem charakteru takie nazwy, jak Region Waloński, Dystrykt Poludniowy, nie różnią się od typu województwo pomorskie, obwód lwowski.

Niekiedy elementowi gatunkowemu towarzyszy dopełniacz od nazwy etnicznej, np. Kraj Basków (Hiszpania, hiszp. País Vasco) lub od innej nazwy geograficznej, np. Kraj Loary (Francja, fr. Pays-de-la-Loire), Dystrykt Kolumbii (Stany Zjednoczone, ang. District of Columbia), Terytorium Stoleczne Islamabadu (Pakistan, ang. Islamabad Capital Territory), Dystrykt Stoleczny Bogoty (Kolumbia, hiszp. Distrito Capital de Bogotá).

Element gatunkowy oraz nazwa miejscowości w mianowniku odróżniła jednostkę Prefektura Wientian w Laosie od innej tamże: Wientian (lao. Nakhon Louang Viangchan i Khouèng Viangchan). Podobny model nazewniczy cechuje wiele rozbudowanych form oficjalnych, np.: Wolne Hanzeatyckie Miasto Hamburg (Niemcy, forma krótka Hamburg; niem. Hamburg i ofic. Freie und Hansestadt Hamburg), Region Autonomiczny Trydent-Górna Adyga (Włochy, forma krótka Trydent-Górna Adyga; wł. Trentino-Alto Adige, ofic. Regione Autonoma TrentinoAlto Adige), Specjalny Region Administracyjny Hongkong (Chiny, forma krótka Hongkong; ang. Hong Kong, ofic. Hong Kong Special Administrative Region).

\section{PODSUMOWANIE}

We współczesnym dyskursie onomastycznym przekonanie o nieostrości i umowności granic toponimii proprialnej wydaje się powszechne. W tej dyskusji wyraźnie wybrzmiewa głos praktyków związanych z urzędowym ustalaniem nazw geograficznych, takich jak językoznawcy: Vincent Blanár (1976), Kazimierz Rymut 
(2003), Rudolf Šrámek (2015), kartografowie: Janusz Gołaski (2002) i Andrzej Czerny $(2011,2021)$. Jeśli przyjąć, że proprialność jest cechą stopniowalną, to nazwy jednostek administracyjnych należałoby sytuować w strefie przejściowej między nazwami własnymi i pospolitymi, podobnie jak w języku polskim np. nazwy mieszkańców ${ }^{13}$.

Różny jest też status konkretnych nazw jednostek administracyjnych w zbiorze polskich choronimów. W proprialnym centrum znajdują się nazwy homonimiczne z nazwami miejscowości i regionów, np. pol. Wałbrzych (nazwa powiatu grodzkiego), austr. Tyrol. Nieco dalej od centrum mieszczą się nazwy wieloelementowe z komponentem proprialnym i elementem gatunkowym, np. Kraj Basków, Kraj Loary, Bazylea-Okręg, Terytorium Stołeczne Islamabadu oraz typ Wielki Londyn. Na pograniczu nazw własnych i pospolitych lokowałabym deskrypcje typu Prowincja Centralna, Region Stoteczny; opisują one pojęcia jednostkowe z wykorzystaniem słownictwa apelatywnego. Nazwy zawierające termin gatunkowy i przymiotnik odmiejscowy (od nazwy miasta lub regionu) z punktu widzenia ortografii w całości należą do zbioru nazw pospolitych, np. województwo podlaskie, powiat otwocki, rejon birżański, obwód brzeski, jednak pojęciowo zaliczyłabym je do pasa przejściowego między apelatywami i propriami.

Nazewnictwo jednostek administracyjnych, zarówno w Polsce, jak i innych krajach na świecie, poprzez systemowość oraz urzędowy sposób utworzenia i ustalenia zbliżone jest do terminologii specjalistycznej, chociaż ze względu na swą heterogeniczną naturę nigdy zapewne nie osiągnie takiej jednolitości i spójności, jaka cechuje systemy terminologiczne, stosowane np.w geografii regionalnej. Hybrydowy charakter (onimiczno-terminologiczny) mają zwłaszcza nazwy wieloelementowe z terminem lub elementem gatunkowym. Sposób zapisu takich nazw pozostaje w moim mniemaniu otwarty. Od lat utrzymuje się różnica w ogólnych zasadach ortograficznych i instrukcjach kartograficznych, od lat również uzus rozmija się z polską normą poprawnościową (por. Kornaszewski, Lech, 1989; Czerny, 2021). W sferze publicznej coraz częściej spotyka się nazwy geograficzne w formie zbliżonej do oryginału, zwiększa się również wpływ ortografii angielskiej, która uwzględnia w szerszym zakresie niż polska — pisownię wielką literą.

${ }^{13}$ Według polskiej normy językowej nazwy etniczne i nazwy mieszkańców regionów są nazwami własnymi, natomiast nazwy mieszkańców miast i wsi — pospolitymi. Por. cytat: „, [...] niełatwo zrozumieć, dlaczego Krakowiak 'mieszkaniec regionu' jest bardziej nazwą własną niż tenże krakowiak zamieszkały w samym Krakowie" (Kornaszewski, Lech 1989, s. 279). 


\section{SKRÓTY}

$$
\begin{aligned}
& \text { ang. — angielski } \\
& \text { arab. — arabski } \\
& \text { austr. — austriacki } \\
& \text { błr. — białoruski } \\
& \text { boś. — bośniacki } \\
& \text { chorw. — chorwacki } \\
& \text { czes. — czeski } \\
& \text { duń. — duński } \\
& \text { fr. — francuski } \\
& \text { hiszp. — hiszpański } \\
& \text { jedn. — jednostka } \\
& \text { kaz. — kazachski } \\
& \text { kir. — kirgiski } \\
& \text { lao. — laotański } \\
& \text { lit. — litewski } \\
& \text { mong. — mongolski } \\
& \text { niem. — niemiecki } \\
& \text { ofic. — oficjalnie } \\
& \text { pol. — polski } \\
& \text { port. — portugalski } \\
& \text { ros. — rosyjski } \\
& \text { serb. — serbski } \\
& \text { słc. — słowacki } \\
& \text { tadż. — tadżycki } \\
& \text { turkm. — turkmeński } \\
& \text { ukr. — ukraiński } \\
& \text { uzb. — uzbecki } \\
& \text { wł. — włoski }
\end{aligned}
$$

\section{LITERATURA}

Biolik, M. (2009). Homonimy onomastyczne. Różne sposoby interpretacji [Onomastic homonyms. Various ways of interpretation]. W: Warchoł, S. i Jastrzębski, M. (red.), Rozprawy Slawistyczne: 22: Stowiańskie homonimy apelatywno-onimiczne i onimiczno-onimiczne $w$ diachronii i synchronii [Slavic Appellative-Onymic and Onymic-Onymic Homonyms in Diachrony and Synchrony] (s. 33-47). Lublin: Wydawnictwo UMCS.

Blanár, V. (1976). Lingvistický a onomastický status vlastného mena [Linguistic and onomastic status of a proper name]. Onomastica, 21, 5-18.

Czerny, A. (2011). Teoria nazw geograficznych [Theory of Geographical Names]. Warszawa: Instytut Geografii i Przestrzennego Zagospodarowania PAN.

Czerny, A. (2021). Problematyka polskich egzonimów z punktu widzenia kartografa [The issue of Polish exonyms from a cartographer's point of view]. W: M. Rutkowski i A. Hącia (red.), Nazwy własne w języku i społeczeństwie [Names in Language and Society] (s. 75-92). Olsztyn: Wydawnictwo UWM. 
Garcarz, M. (2016). Stownik slangu kierowców. Slangowe rozwinięcia skrótów wyróżników powiatów na polskich tablicach rejestracyjnych [A Dictionary of Drivers' Slang. Slang Abbreviation Expansions of County Codes on Polish Vehicle Registration Plates]. Szczecin: Volumina.pl Daniel Krzanowski.

Gołaski, J. (2002). Zbieranie i opracowywanie nazw geograficznych. Przewodnik toponimiczny. Cz. I: Zbieranie nazw w terenie [Collecting and Processing Geographical Names. A Toponymic Guide. Part One: Collecting Names in the Field]. Warszawa: GUGiK.

Karpluk, M. (1986). Staropolskie nazwy krajów egzotycznych: Afryka, Ameryka, Azja — przegląd derywatów [Old Polish names of exotic lands: Africa, America, Asia - an overview of derivatives]. Onomastica, 30, 146-158.

Kondracki, J. (1969). Systemy podziału regionalnego i nazwy jednostek regionalnych [Systems of regional divisions and names of regional units]. W: J. Kondracki (red.), Podstawy regionalizacji fizycznogeograficznej [The Basics of Physiographical Regionalisation] (s. 99-125). Warszawa: PWN.

Kornaszewski, M. i Lech, Ł. (1989). Społeczne pojęcie nazwy własnej a polska norma ortograficzna [Social concept of proper name and the Polish spelling norm]. W: M. Majtán (red.), Aktuálne úlohy onomastiky z hl'adiska jazykovej politiky a jazykovej kultúry [Current Tasks of Onomastics in Terms of Language Policy and Language Culture] (s. 275-281). Bratislava: Jazykovedný ústav L'udovita Štúra Slovenskej akadémie vied.

Malec, M. (2003). Stownik etymologiczny nazw geograficznych Polski [An Etymological Dictionary of Poland's Geographical Names]. Warszawa: PWN.

Mazur, M. (1961). Terminologia techniczna [Technical Terminology]. Warszawa: Wydawnictwa Naukowo-Techniczne.

Olivová-Nezbedová, L. (2002). Onomastická terminologie [Onomastic terminology]. W: E. Rzetelska-Feleszko, A. Cieślikowa i J. Duma (red.), Stowiańska onomastyka. Encyklopedia [Slavic Onomastics. Encyclopedia] (t. 1, s. 83-84). Warszawa-Kraków: Towarzystwo Naukowe Warszawskie.

PN-ISO 704 = Działalność terminologiczna. Zasady i metody [Terminological Work. Principles and Methods] (2012). Warszawa: Polski Komitet Normalizacyjny.

Polskie nazwy własne = Rzetelska-Feleszko, E. (red.). (1998). Polskie nazwy własne. Encyklopedia [Polish Proper Names. Encyclopedia]. Warszawa-Kraków: Towarzystwo Naukowe WarszawskieInstytut Języka Polskiego PAN.

Rymut, K. (2003). Granica czy sfera przejściowa między nomen appellativum a nomen proprium? [A borderline or a transitional zone between nomen appellativum and nomen proprium?]. W: K. Rymut (red.), Szkice onomastyczne i historycznojęzykowe [Sketches in Onomastics and Historical Linguistics] (s. 9-12). Kraków: Instytut Języka Polskiego PAN [Przedruk z: Slavica Ludensia, 7. Sueco-Polonica. Materiaty z drugiej polsko-szwedzkiej konferencji slawistycznej, Forsakar (Szwecja), 15-18 VI 1979, Lund, s. 175-180, 1979].

Sagan-Bielawa, M. (2017). Nazwy województw wśród nazw własnych — funkcja, struktura, wariantywność [Names of voivodeships among proper names - function, structure, variability]. Język Polski, 97(2), 72-84.

Siatkowski, J. (2006). Obce nazwy geograficzne w języku czeskim i polskim. Studium konfrontatywne [Foreign Geographical Names in Czech and Polish. A Comparative Study]. Warszawa: Uniwersytet Warszawski. Wydział Polonistyki. Instytut Slawistyki Zachodniej i Południowej.

Słowiańska onomastyka = Rzetelska-Feleszko, E., Cieślikowa, A., i Duma, J. (red.). (2002-2003). Słowiańska onomastyka. Encyklopedia [Slavic Onomastics. Encyclopedia] (t. 1-2). WarszawaKraków: Towarzystwo Naukowe Warszawskie.

Stew art, G.R. (1975). Names on the Glob. New York: Oxford University Press.

STUS = Stownik terminów używanych przy standaryzacji nazw geograficznych [Dictionary of Terms for Standardization of Geographical Names]. (2014). Tłum. M. Łukasik. Warszawa: GUGiK. (oryg.: Glossary of Terms for Standardization of Geographical Names, Ed. N. Kadmon, United Nations, New York 2002). 
Šrámek, R. (2015). Propriální sfera jazyka a hranice vlastních jmen [The proprial sphere of a language and the borders of proper names]. W: I. Valentová (red.), 19. slovenská onomastická konferencia. Bratislava 28.-30. apríla 2014. Zbornik referátov [19 ${ }^{\text {th }}$ Slovak Onomastic Conference. Bratislava 28-30 April 2014. Proceedings] (s. 46-54). Bratislava: Veda.

TG = Wolnicz-Pawłowska, E. i Zych, M. (2010). Toponymic Guidelines of Poland for Map Editors and Other Users (Polski przewodnik toponimiczny dla redaktorów map i innych użytkowni$k o ́ w)$. Fourth revised edition. GUGiK.

UWPNG = Zych, M. (red.). (2019). Urzędowy wykaz polskich nazw geograficznych świata [Official List of Polish Geographical Names of the World]. Oprac. Komisja Standaryzacji Nazw Geograficznych poza Granicami Rzeczypospolitej Polskiej przy głównym Geodecie Kraju. Wyd. 2 zaktualizowane. Warszawa: GUGiK.

Włoskowicz, W. (2021). Uzus toponimiczny. Zarys teorii na przykładzie polskiej toponimii Huculszczyzny [Toponymic Usus. An Outline of Theory on the Example of the Polish Toponymy of the Hutsul Region]. Kraków: Instytut Języka Polskiego PAN.

Zierhoffer, K. i Zierhofferowa, Z. (2000). Nazwy zachodnioeuropejskie w języku polskim a zwiazki Polski z kultura Europy [Western European Names in the Polish Language and Poland's Relations with European Culture]. Poznań: Wydawnictwo Poznańskiego Towarzystwa Przyjaciół Nauk.

Zierhoffer, K. i Zierhofferowa, Z. (2007). Polska a Europa w świetle nazw geograficznych [Poland and Europe in the Light of Geographical Names]. Poznań: Wydawnictwo „Poznańskie Studia Polonistyczne".

Zierhoffer, K. i Zierhofferowa, Z. (2011). Nazwy geograficzne Europy w języku polskim. Dziedzictwo i wspótczesność [Geographical Names of Europe in the Polish Language. Heritage and the Present Day]. Poznań: Wydawnictwo Naukowe UAM.

Zych, M. (2014). Nazwy państw w języku polskim jako przykład stosowania egzonimów i endonimów [Names of countries in the Polish language as an example of using exonyms and endonyms]. Prace Językoznawcze, 16(2), 95-104.

\section{SUMMARY}

\section{THE PLACE OF THE NAMES OF ADMINISTRATIVE UNITS IN CHORONYMY}

Names of administrative units belong to choronyms. They are located in a transitional zone between proper names and appellatives. The prototypical centre of the category of properhood includes names of administrative units that are homonymic to names of localities and regions, e.g. Rzeszów (city county), Tyrol (Austria, $1^{\text {st }}$ order administrative unit). Further from the category's centre there are multi-element names comprising a proprial component and a generic element, e.g. Kraj Basków, Kraj Loary, Bazylea-Okręg, Terytorium Stoteczne Islamabadu, Prefektura Wientian. On the borderline between proper names and appellatives there are descriptions like Prowincja Centralna, Region Stoleczny which describe individual concepts with appellative vocabulary. Names consisting of a generic term and an adjective derived from a place name belong to appellatives, e.g. województwo podlaskie, powiat otwocki, rejon birżański, obwód brzeski.

The spelling of multi-element names comprising a generic term or a generic element remains an open issue because there is a discrepancy between general orthographic rules and the usus.

Keywords: geonyms, choronyms, names of administrative units, exonyms 